FROM CLASSICAL ECONOMICS TO DEVELOPMENT ECONOMICS 
Also by Gerald M. Meier

ASIAN DEVELOPMENT (co-author)

ECONOMIC DEVELOPMENT

EMERGING FROM POVERTY: The Economics that Really Matters

EMPLOYMENT, TRADE, AND DEVELOPMENT

FINANCING ASIAN DEVELOPMENT

INDUSTRIAL ADJUSTMENT IN SUB-SAHARAN AFRICA

(co-editor)

INTERNATIONAL ECONOMIC REFORM: Collected Papers of

Emile Despres (editor)

INTERNATIONAL ECONOMICS: Theory of Policy

INTERNATIONAL TRADE AND DEVELOPMENT

LEADING ISSUES IN ECONOMIC DEVELOPMENT

PIONEERS IN DEVELOPMENT (editor)

POLITICS AND POLICYMAKING IN DEVELOPING

COUNTRIES: Perspectives on the New Political Economy (editor)

PRICING POLICY FOR DEVELOPMENT MANAGEMENT

PROBLEMS OF COOPERATION FOR DEVELOPMENT

PROBLEMS OF TRADE POLICY

PROBLEMS OF A WORLD MONETARY ORDER

THE INTERNATIONAL ECONOMICS OF DEVELOPMENT 


\section{From Classical \\ Economics to \\ Development Economics}

Edited by

Gerald M. Meier

Konosuke Matsushita Professor of International

Economics and Policy Analysis, Emeritus

Stanford University

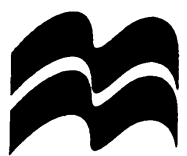


First published in Great Britain 1994 by

MACMILLAN PRESS LTD

Houndmills, Basingstoke, Hampshire RG21 6XS

and London

Companies and representatives

throughout the world

A catalogue record for this book is available

from the British Library.

ISBN 978-1-349-23344-1 ISBN 978-1-349-23342-7 (eBook)

DOI 10.1007/978-1-349-23342-7

First published in the United States of America 1994 by

ST. MARTIN'S PRESS, INC.,

Scholarly and Reference Division,

175 Fifth Avenue,

New York, N.Y. 10010

ISBN 978-0-312-12033-7

Library of Congress Cataloging-in-Publication Data

From classical economics to development economics / edited by Gerald M. Meier.

p. $\mathbf{c m}$.

Includes index.

1. Economic history. 2. Economic development-History.

3. Classical school of economics. 4. Asia-Economic conditions.

5. Asia-History. 6. Development economics. I. Meier, Gerald M.

HC51.F76 1994

$330.09-\mathrm{dc} 20$

94-37497

CIP

(C) Gerald M. Meier 1994

Softcover reprint of the hardcover 1st edition 1994 978-0-333-60414-4

All rights reserved. No reproduction, copy or transmission of this publication may be made without written permission.

No paragraph of this publication may be reproduced, copied or transmitted save with written permission or in accordance with the provisions of the Copyright, Designs and Patents Act 1988, or under the terms of any licence permitting limited copying issued by the Copyright Licensing Agency, 90 Tottenham Court Road, London WIP 9HE

Any person who does any unauthorised act in relation to this publication may be liable to criminal prosecution and civil claims for damages.

Transferred to digital printing 1998

02/040 March 1998 
To Hla Myint - a leader on the development frontier who for more than four decades has enriched the subject with his reinterpretation of the dynamics of classical economics, welfare economics, and the history of economic thought.

Generations of students, professional economists, and development practitioners have benefited from the breadth and quality of his insights.

In his honor, former students, colleagues, and friends now contribute these essays. 


\section{Contents}

Preface ix

Notes on the Contributors $\quad \mathrm{xi}$

1 Introduction 1

Gerald M. Meier

2 The "Progressive State" in Classical Economics 5

Gerald M. Meier

$3 \quad$ In Praise of the Classics 28

Deepak Lal

4 British Classical Economists and 51

Underdevelopment in India

William J. Barber

5 Natural Resources, Vent-for-Surplus, and the 68

Staples Theory

Ronald Findlay and Mats Lundahl

6 Vent for Surplus, the Subsistence Fund, and the

Evolution of Money

P. J. Drake

7 Exports and Economic Growth

R. M. Sundrum

8 Peasant and Plantation in Asia

Yujiro Hayami

9 Traders and Development

Peter Bauer and Gerald M. Meier

10 Development as a Societal Problem in a Colonial

Society

W. W. Rostow 
11 From Colonial Economics to Development

Economics

173

Gerald M. Meier

12 Gamagori: In Retrospect

197

H. W. Arndt

13 Structural Adjustment Policy: Asian Experience

Shigeru Ishikawa

14 Government and Economic Growth

Lloyd G. Reynolds

15 The Future in Perspective

242

Gerald M. Meier

Index 


\section{Preface}

Most development economists are versed only in the post-World War II period of their subject. But economic growth was a major concern in the eighteenth century, and colonial economics and policy commanded much attention in the nineteenth and first half of the twentieth centuries. A return to these earlier concerns can now provide present-day development economists with a greater appreciation of the intellectual history of their subject. Even more, such a return mighi strengthen the conceptual and empirical foundations of the subject. These are this book's objectives.

The contents range from a general exposition of the relevance of classical economics for development issues to specific studies of countries and periods in terms of export-led development, colonial policy, colonial economic thought, and the role of government. Taken as a whole, the volume may widen the perspective of development economics and encourage fresh thinking for the future in light of the past.

Special appreciation is extended to all the contributors. As a warm personal tribute to Hla Myint, each contributor undertook his assignment most generously and enthusiastically. And their essays have been contributed with the highest professional care.

Ronald Findlay, Deepak Lal, and Heinz Arndt have been most helpful in advising me on the volume's contents and contributors.

Support from the Economic Development Institute of the World Bank is also gratefully acknowledged. David Davies of the World Bank was especially encouraging, and it is satisfying to know that development practitioners recognize the value of the larger and longer perspective, as represented in this book.

GERALD M. MEIER 


\section{Notes on the Contributors}

H. W. Arndt is Emeritus Professor of Economics at the Australian National University and Visiting Fellow in its Development Studies Centre. In the last thirty years he has worked largely on Indonesia and other parts of the Asian-Pacific region. He is editor of Asian-Pacific Economic Literature and author of Economic Development: The History of an Idea (1987), among other works.

William J. Barber is Andrews Professor of Economics at Wesleyan University. His degrees are from Harvard University (AB) and University of Oxford (BA, DPhil). He is author of numerous studies in economic development and the history of economic thought. These interests are combined in his British Economic Thought and India, 1600-1858 (1975).

Lord (Peter) Bauer is a Fellow of Gonville and Caius College, Cambridge, Professor of Economics, Emeritus, at the London School of Economics, and a Fellow of the British Academy. As a pioneer in development, he published The Rubber Industry (1948) and West African Trade (1954), and since then has written extensively on major issues in the field of economic development.

P. J. Drake is Vice-Chancellor of Australian Catholic University. His previous academic appointments were in The University of New England, where he was Deputy Vice-Chancellor and Head of the Department of Economics, The University of Melbourne and The Australian National University. He has held visiting fellowships in the University of Manchester and the University of London, Institute of Commonwealth Studies. He has been an adviser to the World Bank, the Australian International Development Assistance Bureau and various governments in the Pacific region. Professor Drake has pub lished many journal articles and several books, including Money, Finance and Development.

Ronald Findlay is Ragnar Nurkse Professor of Economics at Columbia University. His degrees are from Rangoon University and MIT. Specializing in international trade and economic development, he has written 
numerous books and articles, as well as being a consultant to international organizations.

Yujiro Hayami is Professor of International Economics at Aoyama Gakuin University in Tokyo. His previous appointments were Professor of Economics at the Tokyo Metropolitan University and economist at the International Rice Research Institute. He has held research awards from the Japanese Society of Agricultural Economics and the American Agricultural Economic Association, and is author of Japanese Agriculture under Siege and Agricultural Development: An International Perspective (with V. W. Ruttan).

Shigeru Ishikawa is Professor of Economics at Aoyama Gakuin University, Tokyo and Professor Emeritus, Hitotsubashi University. He is an authority on Asian economic development, particularly People's Republic of China. He is the author of Economic Development in Asian Perspective (1967) and numerous other publications on agriculture, technology and employment in development.

Deepak Lal is the James Coleman Professor of International Development Studies at UCLA, and Professor of Political Economy at University College London. He is the author of numerous articles and books on development, including The Poverty of Development Economics and The Hindu Equilibrium. He has advised a number of governments in developing countries and has worked for various international organizations including the World Bank.

Mats Lundahl is Professor of International Economics at the Stockholm School of Economics. He is the author of many books on international trade and development, with special application to the Caribbean and Africa.

Gerald M. Meier is Konosuke Matsushita Professor of International Economics and Policy Analysis, Emeritus at Stanford University. His degrees are from Reed College (BA), University of Oxford (BLitt), Harvard University ( $\mathrm{PhD})$. Meier is the author of a number of books in international economics and economic development. Now in its 6th edition is his Leading Issues in Economic Development. He was also editor of the World Bank's Pioneers in Development (1984) and Pioneers in Development, Second Series (1986). 
Lloyd G. Reynolds was born in Canada and received his BA from the University of Alberta, MA from McGill University, and his PhD degree from Harvard University. He is an applied comparative micro-economist, who has made contributions to industrial organization and public control, wage theory, comparative economics, and development economics. In 1985, he published Economic Growth in the Third World, 1850-1980. In addition to a dozen or so research monographs, he is the author of texts on principles of economics and on labor economics and industrial relations. He was the Founder and first Director of the Economic Growth Center at Yale University, and is Sterling Professor of Economics Emeritus at Yale.

W. W. Rostow is Rex G. Baker Jr Professor Emeritus of Political Economy at the University of Texas at Austin. As a pioneer in development, he published The Process of Economic Growth (1952) and The Stages of Economic Growth (1960). Among his many books in economic history and development is his Theorists of Economic Growth from David Hume to the Present (1990).

R. M. Sundrum was educated in economics at Rangoon University and had his first academic appointment there. Since then, he has been with UNESCO, ESCAP and the World Bank. He has been a visiting professor at Columbia University, Delhi University, the University of Kerala and Dalhousie University, and has been a consultant to the IMF and ILO. He was a Professorial Fellow in Economics at the Australian National University, 1970-89. His most recent book is Economic Growth in Theory and Practice (1991). 
"Our interpretation of the classical outlook on the economic problem, if accepted, seems to cast a serious doubt on the practice of taking it for granted that the central problem of the classical economists was to demonstrate the 'allocative efficiency' of the equilibrium adjustments to consumers' demand in the free market. ...The central principle, which successfully unifies the various classical economic doctrines from Adam Smith to J.S. Mill, embodies the following fundamental proposition: viz. the economic welfare of society can be more effectively promoted (i) by increasing the physical productivity of labour, and (ii) by increasing the total volume of economic activity, rather than by tamely accepting the given quantity of productive resources and making refined adjustments in allocating them among different industries. From this follow the two major canons of classical economic policy, (i) free trade which extends the scope of division of labour and brings fresh resources into the productive framework, and (ii) capital accumulation which enables society to maintain a greater quantity of labour...

"After all, even when the economic welfare of society is regarded as consisting in the satisfaction of individuals' wants, it cannot be denied that this subjective economic welfare is as much quantitatively affected by the techno-institutional factors as by the equilibrium process of the market. Or perhaps even more. Therefore, it is not surprising that after decades of work on the 'allocative' problem many modern economists should have turned their attention to such problems as output per man hour, the extent of unused capacity, the socially desirable rate of investment, etc., problems having a distinctly classical flavour."

- Hla Myint, Theories of Welfare Economics (1948), pp. 12, 14. 